\title{
The En Bloc Sale mechanism as a method of strata scheme termination and urban renewal: a review
}

\author{
S. Zakiah \& H. Khadijah \\ Department of Real Estate, Faculty of Geoinformation and Real Estate, \\ Universiti Teknologi Malaysia, Malaysia
}

\begin{abstract}
The increase of population has an impact on the physical development sector. Thus, various initiatives are implemented so that the physical development of land resources are used optimally and efficiently. One of the development initiatives undertaken is the introduction of the multi-storey building, also known as strata development. Strata development is seen as one of the efficient methods of construction, especially in urban areas. However, there have been issues and challenges related to the strata development resulting in the abandoned development. This will cause a negative impact in the long term, for example in terms of safety, health and sustainability aspects in development. Due to the continuation of this problem, there are initiatives that have been introduced and practiced in some countries, namely En Bloc Sale for strata building. The idea behind this concept is to encourage urban renewal in countries or cities with land scarcity issues. Matters discussed in this research include the concept of En Bloc Sale, process and legal framework used based on experience in Singapore. Accordingly, this research will be conducted in a qualitative method in which it will rely on the analysis of the relevant statutes, rules, regulations, books, journals, articles, theses, seminar papers, electronic materials and various newspaper reports. This research is expected to review En Bloc Sale mechanism as a method of urban renewal and strata scheme termination.

Keywords: strata scheme, termination of strata scheme, urban renewal, En Bloc Sale.
\end{abstract}




\section{Introduction}

The growth of the human population and migration had led to large urban density all over the world. To ensure basic human needs in term of housing are met, multistorey housing or also known as strata scheme developments have been introduced. Nowadays, life in strata scheme development has become a lifestyle, even the offer of a strata scheme development is also rising due to high demand, especially in urban areas that have a limited land supply. The Urban area offers many employment opportunities from various industrial sectors as well as the administration have a wide range of public facilities and good accessibility. Malaysia is no exception to this strata scheme trend. Statistics by Malaysia Commissioner of Building (COB) Annual Report 2014 shows a total of 15,621 strata scheme property has been recorded [1]. The 10th Malaysia Plan has drafted a strategy in promoting the sustainable cities in line with the National Development Policy [2]. Cities need to grow in a sustainable manner as they build the infrastructure and institutions needed to uplift the quality of life. Therefore, the development of strata schemes is seen as a practical alternative to conventional housing developments for the realization of national development policies. In Malaysia, in early 70's, strata scheme development has been introduced due to the impact of government policy granting housing loans for civil servants on a lowinterest rate at $4 \%$. The government also provides requirements for banks to give loans to the poor to buy low-cost houses. This has stimulated the housing industry and increased demand for residential real estate development. At this time, many strata scheme developments have been developed in Kuala Lumpur and other major cities [3].

However, there are some issues arising from the development of strata scheme which resulted in the need for redevelopment in urban area. Among the main problems encountered is in terms of dilapidated building condition. Infrastructure development has to deal with its lifespan including strata scheme development. There are several factors determining building lifespan, these include: building materials, the change of building's surrounding context, the changing needs of its occupant population over the years, or architectural technology that becomes obsolete or is no longer state-of-the-art [4]. Life expectancy of building especially strata scheme development is like time bomb. This is because of the natural decay, ageing and inadequate or no maintenance [5]. For the strata scheme development Management Corporation often face difficulty in obtaining consensus on various aspect of managing the development [6]. As a consequence, this will impact, in physical terms, the buildings that become obsolete and will affect the residents or unit owners in aspects of safety, comfort, healthy living and sustainability. Moreover, some other countries that faced scarcity of land need to redevelop urban area to give the area a better potential in economic and social aspects. Urban renewal also involves the strata scheme area to be redeveloped. Therefore, relevant legislation should be clear for strata schemes to ensure the flexibility with current development needs [7]. To facilitate the process of urban renewal, Singapore has implemented En Bloc Sale method for the strata scheme. The En Bloc Sale is seen as one initiative to solve issues that arise involving strata scheme termination [7]. 
Therefore, this paper focuses on the issue of strata scheme termination using En Bloc Sale method. Even though this method not yet be implemented in Malaysia, this discussion is relevant to other urban areas looking to redevelop strata scheme. Throughout the paper, comparisons were made with the situation from a few countries that had implemented method of strata scheme termination regarding the redevelopment of multi-storey housing. This paper is based on a review of available policy and academic literature as well as legislation governing the strata scheme development.

\section{Strata scheme}

High-rise has become the most commonly built form of the last century, as a tool to battle sprawl and intensifies urban density [8]. High rise housing is known as multi-storey housing or strata scheme. Towers [9] defined multi-storey housing as any purpose-built block or estate comprising flats and maisonettes. Multi-storey housing or strata scheme is a development of terraced properties which divides the building or land into parcels, accessories parcels and common property accessory [10]. In other words, strata scheme refers to a system of ownership whereby a building is divided into portions known as 'lots'. In addition to each individual lot, each owner also shares ownership of the common property. Due to the development of these strata schemes consolidating ownership in many of the building blocks, it has its own management system and is also slightly different to the management system of a landed property housing scheme. Each individual lot owner is responsible for maintaining their own property. However, the common property needs to be maintained collectively by all the lot owners through levy payment systems

Strata title allows individual ownership as part of a property, combined with shared ownership in the remainder through a legal entity called the owner's corporation or management corporation, strata company or community association, depending on state or territory of residence and the type of scheme thus that also the main factor that boosts the popularity of strata scheme $[11,12]$. In addition, strata title is important as a proof of ownership for the purposes of the transaction. Strata title thus introduced a whole new market for properties that banks were willing to use mortgages for [13]. Strata title provides a key property rights mechanism to deliver medium-density and high-density development [14]. In future, strata scheme development seems to provide the major source of urban housing in the future and is a key response to urban planning challenges in metropolitan cities $[12,15]$.

\section{Urban renewal and strata scheme termination}

The redevelopment has been defined as a process in which the structure of the existing site was purchased and demolished to create land for new uses [16]. Urban Renewal represents adjustment process by which the existing stock of infrastructure development is gradually being replaced with higher value. Thus, the relative physical buildings and existing infrastructure nearby can be a greater 
incentive to maximize land use and land resources through the collective sales and redevelopment [17]. Urban renewal has been designed to remove blighted areas, by demolishing the old building and build a new one for them [18]. Urban renewal policy became more complex due to the properties of the multi-dimensional problem such as the deterioration of the quality of housing, poverty, unemployment, social exclusion, isolation, low quality of public spaces, etc. [19].

Some metropolitan cities in the world had devised urban renewal plans to overcome dilapidated buildings in urban area. Because the phenomena of land scarcity in metropolitan cities, the planning authorities were charged with the task of maximizing land use through enhance measures, including re-zoning, increased plot ratio and redevelop potential area. As a result of planning revision for urban renewal, many properties which were previously under-utilised, were translated into highly-prized assets [20]. Intolerable strata scheme with dilapidated conditions in the growing cities will affect directly urban landscapes. The initiative to make "better use" of central urban land gave birth to the idea of slum clearance [21]. The termination of a strata scheme is required as a first step in creating a new development on a site and therefore if any redevelopment is to occur on the site of an existing strata scheme, that scheme must first be terminated. There are three main scenarios in which strata-titled buildings should be terminated [13]:

1. A strata building needs a lot of restoration work it will be more costly to maintain than to demolish and rebuild

2. A building or strata that have not been utilized to the maximum potential for development, or in areas that have been re-zoned to allow development of higher density, and there are profits to be made by the property owner.

3. A strata building or other type of building located in the area that can be targeted for bigger urban renewal projects.

Termination of a strata scheme method for the redevelopment area or urban renewal is different for some countries. Termination of strata scheme is based on the legislation of strata title that is applicable in each country. There are few comparisons discussed as shown in Table 1.

Table 1: $\quad$ Method of strata scheme termination and total minimum threshold (source: Land Administration Journal Vol. 4. No. 1 2014, JKPTG).

\begin{tabular}{|c|c|c|c|}
\hline Country & $\begin{array}{c}\text { Full consent } \\
(\%)\end{array}$ & $\begin{array}{c}\text { Majority consent } \\
(\%)\end{array}$ & Method \\
\hline $\begin{array}{c}\text { Australia } \\
\text { (New South Wales) }\end{array}$ & & 75 to 90 & $\begin{array}{c}\text { Strata scheme } \\
\text { termination }\end{array}$ \\
\hline Hong Kong & & 80 & Compulsory Sale \\
\hline Singapore & & 90 or 80 & En Bloc Sale \\
\hline Malaysia & 100 & & $\begin{array}{c}\text { Strata scheme } \\
\text { termination }\end{array}$ \\
\hline
\end{tabular}


Terminating strata schemes in Australia under the current legislation in New South Wales, schemes are usually only terminated by an application to the registrar general where $100 \%$ of the lot owners, lessees and mortgagees have agreed to the termination $[22,23]$. There are two mechanisms for terminating a strata scheme in New South Wales (Australia) under Strata Schemes Freehold Development Act 1973 which are by unanimous agreement and by order of the Supreme Court. For the unanimous agreement, it should be $100 \%$ agreement of the owners, leases, mortgagees, chargees, and covenant chargees to terminate the scheme, and sign the application for termination, which is decided by the registrar general. Section 51 of the Strata Schemes (Freehold Development) Act 1973 sets out a procedure whereby any proprietor, mortgagee or owners' corporation may apply to the Supreme Court of NSW to terminate a strata scheme. In practice, very few strata schemes have been terminated in New South Wales as "the normal course of events appears to have been for termination not to take place, because it can be very difficult to secure a 100 per cent vote on any issue" [22-24].

Recently, there has been a significant discussion in New South Wales about whether the termination of a strata scheme should be made easier, especially in cases where the demolition of a building would be in the best interests of the individual lot owners or the community [22]. There are a few alternatives that have been proposed to the current system, including a unanimous agreement, fixed terms for strata schemes; and the cooperative re-development of a strata scheme between existing lot owners and a developer [25]. The most popular alternative has been to base termination on a majority (rather than a unanimous) decision, with proposals ranging from $75 \%$ to $90 \%$ of the owners voting for termination [25].

Redevelopment of a strata scheme in Hong Kong being conducted by the statutory body namely Urban Renewal Authority (URA). URA was setting up to implement a new rigorous and comprehensive approached to overcome the problem of urban decay. In the purpose of redevelopment in Hong Kong, URA uses two methods, which are land resumption and compulsory sales for redevelopment [26]. In Compulsory sale for redevelopment, Ordinance (Cap. 545) also provides for any owner who has not less than $90 \%$ undivided share to apply to the Lands Tribunal to sell the entire undivided share for the purpose of redevelopment [26, 27]. It is a government initiative to boost the redevelopment efforts that reach a critical look at the increased number of dilapidated buildings in Hong Kong. However, it is being revisable in the year 2010. The minimum threshold has been reduced to $80 \%$ undivided share in accordance with age and category of the building [28]. This method can facilitate the process of urban renewal in an efficient way.

Singapore is no exception in the urban renewal process due to scarcity of land. Thus, planners and developers in Singapore are constantly challenged to introduce measures to optimize land use [29]. Urban Redevelopment Authority (URA) is the agencies that responsible for planning and facilitating Singapore's Physical Development. There are three main mechanisms used by the government for urban redevelopments, such as the initiative to improve control over the rental, En Bloc Sale and removing building premium [26, 30]. Legislation of En Bloc Sale or 
known as collective sales in Singapore is located under the LTSA by using the majority consent. The percentage of majority consent is based on the age of the strata scheme. The basic formula if a building is less than 10 years old is that at least $90 \%$ of the owners must agree to sell. If a building is more than 10 years old, $80 \%$ of the owners must agree to the sale [31].

In Malaysia, strata scheme subdivision may be terminated in accordance with the law as stated in the Strata Titles Act 1985. It related to the termination of the strata scheme subdivision specified by section 57(1) of the Strata Titles Act, which provides in respect of the termination of the subdivision of the building [32]. Management Corporation as owner representative in making the application to terminate a strata scheme by requiring a unanimous resolution that is $100 \%$ approval (in the event of termination of strata scheme made the whole unit) in taking action to end the building partitions, and it is subject to court order under subsection 7 [26]. Management Corporation, proprietor or holder of the registered charge may apply to the Court to make an order to direct the termination of the subdivision was made despite the absence of instructions through a unanimous resolution or order of prohibiting the termination, even if the instruction through a unanimous resolution was given as specified in subsection 57(7) Strata Titles Act [32]. Although there is no similar demands or equal emphasis for detailed laws and procedure on termination of strata scheme in Malaysia, trend of legal development on another aspect of strata title shows that Malaysia is following the footstep of another pioneer of jurisdiction as far as strata title are the concern [33].

Based on the discussion above, the different "terminology" is used by certain countries for strata scheme termination. However, the method is actually similar. The process of termination strata scheme aiming to facilitate urban renewal in each country may differ but the method used in the context of the minimum threshold is the adaptation method from each other. Apparently, Malaysia approached on strata scheme termination is different. Nevertheless, the law pertaining to termination of strata scheme in Malaysia is simple and straightforward in comparison with other country. While Singapore has more detailed provisions that ensure transparency and certainty of the process rather than Malaysia [33].

\section{En Bloc Sale}

En Bloc Sale generally refers to a collective purchase of property in the development of certain properties or the sale of a block of apartments and mostly for the purpose of redevelopment. Normally, En Bloc Sale is a sale of all units in the strata or high-rise development to the buyer. The profit from the sale of the strata scheme is then divided among all unit owners. En Bloc Sale often interchangeably referred to as a collective sale [33]. In addition, there are also variations in En Bloc Sale i.e. sale of all units together with the adjacent building or property [34].

The term En Bloc Sale refer to a condition in which parcel is sold as a building block [7]. This definition is supported by Christudasons [14] which stated that En Bloc Sale usually refers to situations in which the building blocks being sold seem as one unit [35]. En Bloc Sale occurs when all the owners sell the entire parcel 
compartment as a block (as a single unit) to a developer or purchaser for the purposes of a comprehensive redevelopment [26]. En Bloc Sale have always been an alternative for strata scheme termination due to multiple ownership will complicate redevelopment matters. En Bloc Sale or also known as collective sales are the type of real estate transactions in which the individual owner of the strata scheme come together to sell their property as a single entity to a single buyer [35]. En Bloc Sale happens when a collective action of more than one owner of residential property, and real estate development deal together to create a union of mutual interest in selling each parcel to get a potential maximum profit with short selling ownership rights to the buyer for the purpose of redevelopment of the land [30].

Due to the shortage of land resources, rapid urban development cannot be accommodated. Therefore, urban renewal and redevelopment should take part to make sure the sustainability of the land resource by the termination of a dilapidated building. Thus, buildings that have reached the stage of obsolescence should be demolished especially strata scheme because it will affect the urban landscape in a negative way. Singapore also has created authorities as the executor of the booming development, namely Urban Redevelopment Authority (URA). The agency will conduct research to study aspects of urban redevelopment as a whole, including aspects of En Bloc Sale [36]. URA also examines the implications of En Bloc Sale in social, economy and development aspect. The Urban Redevelopment Authority also has a Master Plan containing indicators of development in Singapore in the last 10 to 15 years [37].

En Bloc Sale are conducted in Singapore, is controlled by using the method Land Title Strata Act 1968 (LTSA) majority consent [38]. Majority consent, in other words, is an agreement to combine the majority owner of the unit or a separate compartment in an apartment, condominium or office building united collectively to sell their property to developers. The provisions relating to majority consent was introduced in Singapore in 1994 as a facilitator for the implementation of En Bloc Sale in the country [39]. Majority consent agreed in legislative En bloc in Singapore is $80 \%$ or $90 \%$ of the shares and also depends on the age of the building.

There are several factors for individual owner agree to sell their unit and participate in En Bloc Sale. Among these, the increase in profit, an ageing development, desire for capital gains and other economic factors [40]. Implementation of En Bloc Sale for strata scheme termination is an arrangement involving the sale and purchase of high investment value. Despite the occupant compartment or minority groups who objected and have reasons of its own, the process of En Bloc Sale will continue to be run if the minimum threshold set. Therefore, all owners of strata development schemes need to know the procedures or process involved in the implementation of En Bloc Sale, so that the interests of the majority and minority groups awake. The process of En Bloc Sale in Singapore is based on seven (7) phases, as stated in Table $2[35,41]$. 
Table 2: Stage of En Bloc Sale (source: Ministry of National Development/ www.mnd.gov.sg).

\begin{tabular}{|c|c|}
\hline $\begin{array}{l}\text { Phase 1: Pre-Sale } \\
\quad \text { Preparation }\end{array}$ & $\begin{array}{l}\text { Unit (parcel) owners agree and sign the En Bloc Sale } \\
\text { Agreement through the sale committee. General } \\
\text { Meeting will be held to appoint an en bloc lawyer and } \\
\text { property agent, the apportionment of sales proceeds, } \\
\text { and approval of the terms and conditions of the En Bloc } \\
\text { Sale. }\end{array}$ \\
\hline $\begin{array}{l}\text { Phase 2: En Bloc } \\
\text { Sale Agreement }\end{array}$ & $\begin{array}{l}\text { At this stage, minimum threshold results will be } \\
\text { obtained. } \\
80 \% \text { of signatures unit owner are needed if the building } \\
\text { is more than } 10 \text { years old while } 90 \% \text { of signatures are } \\
\text { needed if the building is less than } 10 \text { years old. }\end{array}$ \\
\hline $\begin{array}{l}\text { Phase 3: } \\
\text { Committee } \\
\text { Meeting }\end{array}$ & $\begin{array}{l}\text { Owners will be updated on the total numbers of } \\
\text { committee who have signed the En Bloc Sale } \\
\text { Agreement. The sale committee and any solicitor would } \\
\text { provide information to the owners on the sale proposal } \\
\text { and sales proceeds. }\end{array}$ \\
\hline $\begin{array}{l}\text { Phase 4: Public } \\
\text { Tender Stage }\end{array}$ & $\begin{array}{l}\text { Once the agreement is signed, the sale committee would } \\
\text { find interested buyers through public tender. And } \\
\text { interested buyer would bid for the sales. }\end{array}$ \\
\hline $\begin{array}{l}\text { Phase 5: Post } \\
\text { Tender }\end{array}$ & $\begin{array}{l}\text { The sale committee will evaluate the bids and negotiate } \\
\text { with the developers on details prior to the sale. }\end{array}$ \\
\hline $\begin{array}{l}\text { Phase 6: Legal } \\
\text { Completion }\end{array}$ & $\begin{array}{l}\text { The sale committee and the buyer will obtain an order } \\
\text { from the Strata Titles Board (STB). STB will only } \\
\text { allow the en bloc to proceed once the requirements are } \\
\text { met. After approval by STB, the developer would be } \\
\text { awarded a conditional contract. }\end{array}$ \\
\hline $\begin{array}{l}\text { Phase 7: Decision } \\
\text { Making }\end{array}$ & $\begin{array}{l}\text { The decision is made during this phase, unit owners } \\
\text { who declined the sale can raise an objection to Strata } \\
\text { Title Board. }\end{array}$ \\
\hline
\end{tabular}

The procedure as shown in Table 2 should be carried out before the action of En Bloc Sale. Knowledge of the procedures can keep minority interests through appropriate channels. If there any objections, it must be submitted to the Strata Title Board and can challenge the decision through an appeal to the judiciary system [42]. Owners themselves have to be clear about the process and the procedure of En Bloc Sale. They should state clearly their own reasons why they should or should not participate in the En Bloc Sale. They should also take the initiative to update with the current updates on the market, at which stage has the En Bloc Sale arrived at, and to clarify any doubts with the sale committees. Even though the En Bloc Sale emphasizes the voice of the majority, the minority's 
needs must also be taken into account to achieve a balance between strata scheme owners. The En Bloc Sale mechanism is seen as a method of urban renewal because it facilitates the termination of a strata scheme in an efficient way and on another hand, urban renewal can successfully be carried out in accordance with the planning framework. Furthermore, En Bloc Sale also opens up opportunities for capturing some of the profit of the redevelopment for the public [13]. Although En Bloc Sale issues in delivering equality for minorities who are disagreed were arisen, an amendment on legislation could be recommended. The amendment should be taken into consideration about the interests of minorities and other limitation factors. Undoubtedly this will be very effective and efficient method for urban renewal in the future.

\section{Summary and conclusion}

One major barrier to the redevelopment of land containing existing of strata development is the difficulty of terminating scheme because of multiple ownership in one building. The termination and redevelopment process will need to be managed efficiently so that it actually worked in practice. Moreover, with effective system of strata scheme termination and redevelopment can ensure that developments are both economically viable and feasible within the planning framework. Experiences of Singapore provide important insight into the potential complex consequences of changing strata termination legislation. Stakeholder involvement is required to make the process of strata scheme termination and urban renewal successful. Strata scheme buyer must be concern about any probability their property status to meet the sustainability development. The future of strata scheme can be determined through comprehensive and clear legislation and legal framework especially in term of strata scheme termination. Even though the "terminology" methods were difference, but the implementation remains the same. Moreover, if any country applies En Bloc Sale method, the social impact strategy associated with urban renewal needs to consider prevention, as well as mitigation and compensation [13]. Other than that, legislator and policy maker must have greater involvement with the group of minorities that have banded together to protest En Bloc Sale. It will fix the deficiency of En Bloc Sale existing legislation and make the mechanism of En Bloc Sale as the main method of termination of strata scheme in metropolitan cities.

\section{References}

[1] Kementerian Perumahan dan Kerajaan Tempatan (2015). Laporan COB Tahunan PBT. Kuala Lumpur, Malaysia.

[2] Economic Planning Unit. "Policy, Objective and Framework - RMK6" Retrieved from http://www.epu.gov.my/ Accessed on 20 July 2016.

[3] K. Hussin (2006). "A Critical Evaluation of Certain Aspect of The Strata Titles Act 1985". Unpublished PhD Thesis University of Aberdeen. 
[4] M. L. Lehman "Building Lifespan" retrieved from http://sening architecture.com/8965/how-long-is-your-building-lifespan Accessed on 7th August 2016.

[5] T. Zeeshan (2015) Dilapidation of Buildings: Meaning, Causes and Factors. Retrieved from http://www.yourarticlelibrary.com. Accessed on 1st August 2016.

[6] A. Christudason (2009). Property rights: achieving a fine balance in collective sales of strata developments in Singapore. International Journal of Law in the Built Environment, 1(1), 26-41.

[7] Mohd Shukri Ismail (2014). "Akta Hakmilik Strata 1985 - Evolusi dan Cabaran Masa Hadapan”.Jurnal Pentadbiran Tanah, 4(1). Malaysia. Jabatan Ketua Pengarah Tanah dan Galian Persekutuan.

[8] G. S. Tolley \& V. Thomas (1987). An overview of urban growth: problems, policies and evaluation. The Economics of Urbanisation and Urban Policies in Developing Countries.

[9] G. Towers (2000). Shelter is not enough: transforming multi-storey housing. Policy Press.

[10] Department of Director General of Lands and Mine (2010) What is strata scheme? Retrieved from http://www.kptg.gov.my. Accessed on 20 July 2016.

[11] Strata Community Australia (2016), "Understanding Strata" Retrieved from https://www.stratacommunity.org.au Accessed on 26 July 2016.

[12] R. Goodman (2012). Strata Title: Towards a research agenda for informed planning practice. Strata \& Community Title in Australia for the 21st Century III Conference. Retrieved from www98.griffith.edu.au. Accessed on 23 July 2016.

[13] H. Easthope, S. Hudson \& B. Randolph (2013). Urban renewal and strata scheme termination: balancing communal management and individual property rights. Environment and Planning A, 45(6), 1421-1435.

[14] K. Everton-Moore, A. Ardill, C. Guilding \& J. Warnken (2006). The Law of Strata Title in Australia: A jurisdictional Stocktake, Australian Property Law Journal, 13:1-35.

[15] J. R. Kenworthy (2006). The eco-city: ten key transport and planning dimensions for sustainable city development. Environment and urbanization, 18(1), 67-85.

[16] D. DiPasquale \& W. C. Wheaton (1996). Urban Economics and Real Estate Markets, Englewoods Cliffs, N.J.: Prentice Hall.

[17] A. Christudason (2004). Private sector housing redevelopment in Singapore: a review of the effectiveness of radical strata title legislation. In ENHR Conference. Cambridge.

[18] McGills (2016). "Chapter 1: Urban Renewal". Retrieved from https://www.mcgill.ca. Accessed on 14 July 2016.

[19] R. Kleinhans (2004). Social implications of housing diversification in urban renewal: A review of recent literature. Journal of Housing and the Built Environment, 19(4), 367-390. 
[20] S. Pheng Low (1999). Success factors for managing en bloc property transactions. Property Management, 17(1), 37-48.

[21] N. Carmon (1999). Three generations of urban renewal policies: analysis and policy implications. Geoforum, 30(2), 145-158.

[22] NSW Government, 2004 Strata Schemes in 2004-The Further Issues Discussion paper, Retrieved from_SS_DiscussionPaper.pdf

[23] B. Randolph \& H. Easthope (2007, November). Governing the compact city: The governance of strata title developments in Sydney. In 2007 ENHR International Conference, Sustainable Areas.

[24] H. Easthope \& S. Judd (2010). Living well in greater density. Shelter NSW.

[25] H. Easthope \& W. Randolph (2008). Governing the Compact City: The challenges of apartment living in Sydney. City Futures Research Centre.

[26] Sharifah Khadijah Tuan Hadi (2014). "Cadangan En Bloc Sale di Semenanjung Malaysia dan Perbandingannya Dengan Singapura dan Hong Kong”. Jurnal Pentadbiran Tanah, 4(1). Malaysia. Jabatan Ketua Pengarah Tanah dan Galian Persekutuan.

[27] Bilingual Laws Information System. "Land (Compulsory Sale For Redevelopment) Ordinance" Retrieved from http://www.legislation.gov.hk/ Accessed on 1 July 2016.

[28] K. C. Shin (2008). The optimal time of redevelopment. Unpublished Thesis. The University of Hong Kong

[29] A. Christudason (2005). Optimisation of land use through innovative legislation in Singapore. In Pacific Rim Real Estate Conference, Brisbane, Australia.

[30] T. Foo Sing, \& C. Wan Jenny Lim (2004). Value of Collective Effort: Redevelopment Timing Options of Enbloc Sale Sites in Singapore. Pacific Rim Property Research Journal, 10(2), 193-214.

[31] Ministry of Law. "Changes to the En Bloc Sale legislation" Retrieved from https://www.mlaw.gov.sg. Accessed on 21 July 2016.

[32] Malaysia (2002) Akta Hakmilik Strata 1985 (Akta 318). Kuala Lumpur: International Law Book Services.

[33] N. A. Muhamad (2104). A study on legal framework of termination of strata scheme in Malaysia: lesson learnt from other jurisdiction. International Conference on Social Science and Management (ICSSM 2014) 414-421.

[34] A. Christudason (2005) "Impediments to the success of collective sales: lessons for the property consultant”, Property Management, Vol. 23 Iss: 4, pp. 271-285.

[35] Ministry of National Development (2005). "What is a Collective Sale? Retrieved from http://www.mnd.gov.sg/ Accessed on 17 July 2016.

[36] A. Christudason (2004). Private sector housing redevelopment in Singapore: a review of the effectiveness of radical strata title legislation. In ENHR Conference. Cambridge.

[37] S. Pheng Low (1999). Success factors for managing en bloc property transactions. Property Management, 17(1), 37-48.

[38] Urban Redevelopment Authority (2015) Singapore Master Plan. Retrieved from www.ura.gov.sg. Accessed on 10 August 2016. 
[39] A. Christudason (2010). Legal framework for collective sale of real estate in Singapore: Pot of gold for investors?. Journal of Property Investment \& Finance, 28(2), 109-122.

[40] Legislative Council Secretariat (2010), "Collective sales in Singapore" Retrieved from www.legco.gov.hk Accessed on 29 July.

[41] Ukessay (2015), "Problems and Implications of En Bloc in Singapore" Retrieved from https://www.ukessays.com . Accessed on 5 August 2016.

[42] E. Y. Soh \& B. Yuen (2011). Singapore's changing spaces. Cities, 28(1), $3-10$. 